\title{
Women's Role in Advertising Brands of Various Electronic Gadgets
}

\author{
N. Mathankumar, S. Jeni Theresa, T. Subhalatha
}

\begin{abstract}
This article expounds regarding the matter of brands. The comprehension of brands has changed alongside the occasions and financial atmosphere. The change expects organizations to move their considering brands from a showcasing focused capacity to a core value that includes each part of the association. Current brand thinking never again spins around unmistakable brand properties, for example, logos and hues, these simply make up the obvious brand.

Each new brand need to position and brand itself as an organization that can convey huge included an incentive for the clients, through extending the administration model of conventional publicizing offices. The brand incorporates the organization to advocate straightforwardness and decent variety, Visible correspondence, and purposes of contact with the organization. From the site to the workplace and the unmistakable items. Brands are required to be steady and suitable.
\end{abstract}

\section{Keywords - Organizations, Incentives}

\section{INTRODUCTION}

Brands are in stores, in ads, TV ads and with the web, they are wherever we look, while perusing through the tremendous systems of our inclinations. Brands are very captivating. Most organizations perceive marks yet neglect to see the genuine pith behind the brand or the explanation behind their acquiring conduct. Numerous organizations consider marking to be a procedure that includes just unmistakable perspectives, for example, the visual appearance of an organization[1]-[2].

\section{A. What is brand?}

The word brand, gets from the act of marking. Ranchers and cowpokes the same utilized a steaming hot marking iron to consume the initials of the proprietor on animals. This empowered ranchers to perceive their very own cows and purchasers to recognize the cows of specific ranchers from other, conceivably mediocre ones[3].

A brand is a mix of corporate conduct and qualities, the specialized usefulness and nature of items and the impalpable guarantee the organization imparts in their items

Revised Manuscript Received on December 16, 2019

N. Mathankumar, Department of Science and Humanities, Bharath Institute of Higher Education and Research, Chennai , India. Email: ma.aswinkumar18@gmail.com

S. Jeni Theresa, Department of Science and Humanities, Bharath Institute of Higher Education and Research, Chennai, India. Email: littleflower1812@gmail.com

T. Subhalatha, Department of Science and Humanities, Bharath Institute of Higher Education and Research, Chennai, India. Email: subhalatha.thavasikannan@gmail.com for clients. It is a blend of unmistakable and immaterial credits and tries to make a positive association with the client so as to make motivating force for clients to utilize the results of the organization in the now and later on. A successful brand is a device for the organization to speak with their condition. An appropriately overseen brand additionally gives speculators a feeling of future benefit making capacity and builds the money related estimation of the organization[4]-[7]

\section{B. History of Brands}

Brands were recognized in old Rome, it doesn't imply that brand the board has been comparable for quite a long time. Brands have become a conspicuous aggressive device for organizations just in the very late future

Just by having genuine responsibility for insignificant rights, licenses and trademarks, it very well may be viewed as a sound convention to really put resources into them (Radikaali Brändi, Malmelin, Hakala)[8]-[10]

Coca-Cola, McDonalds, Nokia and Google albeit distinctive in their fields of business, share something noteworthy for all intents and purpose

\section{Elements of Brands}

1. Corporate culture

2. Employees

3. Communications

4. Leadership

5. Reputation

6. Image and visual identity

7. Products

8. Social responsibility

\section{EMERGENCE OF BRANDS}

They initially rose as a methods for separating one item from the other, as a result of the intrinsic contrasts in the nature of the results of various producers and experts. The reason for brands has remained a remarkable same, even today[11]-[14]. They exist with the goal that purchasers promptly realize what they are going to purchase. They speak to considerably more than simply the name of an organization or item.

Today, worldwide brands are at the front line of creating Corporate Social Responsibility (CSR) and the pioneers are profoundly engaged with

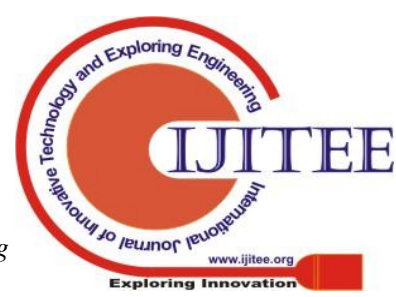


corporate social administration, however which direct move can be made towards arriving at an increasingly proactive strategy for keeping up and empowering others for progressively moral tasks, however out their business sectors.

\section{A. Different sorts of brands}

Brands are not all comparable. They can be isolated into various classifications dependent on what they speak to. A brand can be corporate, for example, Procter and Gamble or it very well may be customer, for example, Colgate. One organization may have responsibility for purchaser marks that speak to items and it can at present have its very own corporate image character that is reflected in work, financial specialist relations and corporate correspondence[15]-[17].

\section{B. Brand Management: A Holistic versus Conventional Approach}

As per the all encompassing perspective on brand the executives, the brand is the spine, focal managing thought and the "DNA" of the organization. Everything about the organization must be inline with the brand so as to convey most extreme incentive to the client. The all encompassing perspective has changed the manner in which brands are overseen, not by a solitary piece of the organization to depict something that could possibly be valid, yet to depict something that the entire organization lives and relaxes. An all encompassing perspective expects organizations to comprehend that to arrive at their objective of making and keeping up a fruitful brand each capacity of the association must participate all the while. A definitive encapsulation of the brand is the focal overseeing figure, the CEO and every one of the representatives of the organization.

The conventional view on marking would likewise think of it as an overwhelming expense for an organization, bringing about undermining its significance. Despite the fact that circumstances are different, this equivalent attitude still exists in progressively customary organizations where the administration may not be as edified on improvements in this division. Numerous organizations still neglect to understand the point and significance of the brand[18]-[20].

To put it plainly, for organizations to make and keep up a fruitful brand their all out brand procedure must be inline with interior procedures.

\section{RESULTS AND DISCUSSIONS}

Marking is tied in with molding the client's involvement in the brand. Each organization has a brand and their clients have a specific brand experience that they have framed by working with the organization[21]-[23]. This reason is valid for organizations both working with singular purchasers and organizations. A fruitful brand and solid brand position additionally makes it conceivable to keep the items premium valued, as customers have such a solid association with the organization's items that they will buy them paying little mind to that reality. A phenomenal case of a solid corporate brand and individual item brands is Apple. Their gadgets are exceptionally fruitful and keep on making record deals, in any event, during a downturn. The Ipod has become an equivalent word for the mp3 player, despite the fact that they are estimated high[24]-[25].

Marking is tied in with conveying brand esteems and ascribes to the intended interest group. This implies the organization doing the marking must have a working learning of the essentials of the procedure and how to go about it. They should understand all the various components that brands include and how they impart the brand. Legitimate learning on the intended interest group ought to likewise be known.

\section{A. Creating a Brand Strategy}

Step 1: Building the Brand Strategy Around Core Values

Step 2: Research in the Brand Strategy

Step 3: Forming the Brand Promise

Step 4: Realization of the brand promise

Step 5: Brand Audit

Step 6: Brand Evaluation

\section{CONCLUSION}

The primary objective of the brand system is to give instrument that make conveying a brand picture conceivable. In actualizing the new brand methodology the needs should be remembered consistently. The primary need is to comprehend the brand, its position and its qualities. Identified with this need is to impart and make a uniform discernment on the brand inside, all through the whole organization. The organization must strengthen its image picture so as to successfully impart it remotely.

The subsequent need is to impart the brand adequately to the intended interest group through practical media and showcasing techniques. The correspondence of the brand is likewise done by each purpose of contact between the organization and its clients. All through the future, the organization will be required to survey the brand methodology and alter it if necessary. Doing this is a need as keeping up a predictable brand picture will in all probability make progress and will help build up an association with the clients. Steady advancement of specialized strategies and brand execution is critical.

\section{REFERENCES}

1) Vasanthi, S. \& Rabiyathul Basariya, S. 2019, "Influence of value analysis and cross training in industry", International Journal of Engineering and Advanced Technology, vol. 8, no. 6, pp. 1810-1811.

2) Velvizhi, R., Sri Gowtham, S. \& Jeya Priya, D. 2019, "Examination of early feedbacks for effective product retailing on E-commerce websites", International Journal of Engineering and Advanced Technology, vol. 8, no. 6 Special Issue 2, pp. 703-706.

3) Anuradha, C., Pothumani, S. \& Kavitha, R. 2019, "A novel method towards E-commerce", International Journal of Engineering and Advanced Technology, vol. 8, no. 6 Special Issue 2, pp. 535-538.

4) Thomas, J. \& Rabiyathul Basariya, S. 2019, "A study on the issues of financial ratio analysis", Indian Journal of Public Health Research and Development, vol. 10, no. 3, pp. 1079-1081.

5) Ramachandran, S. \& Rabiyathul Basariya, S. 2019, "Online marketing study on customer satisfaction and relationship", Indian Journal of Public Health Research and Development, vol. 10, no. 3, pp. 1072-1078. 
6) Priya, R., Vinothini, G. \& Cor Jesu, C.D. 2019, "The mentor-protégé relationship for professional growth", Journal of Advanced Research in Dynamical and Control Systems, vol. 11, no. 9 Special Issue, pp. 1110-1119.

7) Jannifer Rani, N., Bina Pani, S. \& Nimisha, N.S. 2019, "A study on money back polices available in LIC", Journal of Advanced Research in Dynamical and Control Systems, vol. 11, no. 9 Special Issue, pp. 833-839.

8) Saillaja, V., Jhansi Rani, K. \& Catherine, R. 2019, "Global marketing management planning and organization", Journal of Advanced Research in Dynamical and Control Systems, vol. 11, no. 9 Special Issue, pp. 489-493.

9) Saillaja, V., Jhansi Rani, K. \& Catherine, R. 2019, "The new phase of marketing information system", Journal of Advanced Research in Dynamical and Control Systems, vol. 11, no. 9 Special Issue, pp. $482-488$.

10) Thoufiqulla \& Raju, D.V. 2019, "Perception of indian investor towards investment in mutual funds with special reference to mip funds", Journal of Advanced Research in Dynamical and Control Systems, vol. 11, no. 5, pp. 177-183.

11) Jasmine, K.R.M. \& Basariya, S.R. 2018, "A study on the customers benefits on mutual funds", International Journal of Civil Engineering and Technology, vol. 9, no. 4, pp. 45-48.

12) Vasanthi, S. \& Basariya, S.R. 2019, "Pros and cons of on the job training versus off the job training", International Journal of Scientific and Technology Research, vol. 8, no. 10, pp. 671-674.

13) Pavithra, J. \& Ganesan, M. 2016, "A study on awareness and impact of micro-financial schemes", International Journal of Applied Business and Economic Research, vol. 14, no. 8, pp. 5449-5460.

14) Pavithra, J., Dilli Babu, P. \& Ambuli, T.V. 2014, "A study on budgetary control at Maruti Service Masters, Chennai", International Journal of Applied Business and Economic Research, vol. 12, no. 2, pp. 151-161.

15) Gunaraja, T.M. \& Venkatrama Raju, D. 2018, "Determining factors of organisational climate with reference to leadership styles", International Journal of Mechanical Engineering and Technology, vol. 9, no. 9, pp. $1327-1332$

16) Gunaraja, T.M. \& Venkatrama Raju, D. 2018, "The role of job satisfaction and training of employees in determining organisational climate of a selected industry", International Journal of Civil Engineering and Technology, vol. 9, no. 8, pp. 1266-1269.

17) Aarathy, T.S. \& Raju, D.V. 2018, "Performance appraisal and its effects on employees with respect to it sector in Chennai city", International Journal of Civil Engineering and Technology, vol. 9, no. 6, pp. $1535-1538$.

18) Aarathy, T.S. \& Raju, D.V. 2018, "Employee perception towards performance appraisal system in IT sector", International Journal of Mechanical Engineering and Technology, vol. 9, no. 5, pp. 131-135.

19) Porselvi, W., Jublee, D. \& Sivanesan, G. 2018, "A study on factor influencing adoption of technology and innovation in banking industry, tamilnadu, India", International Journal of Mechanical Engineering and Technology, vol. 9, no. 5, pp. 789-800.

20) Akessa, G.M. and Dhufera, A.G., 2015. Factors That Influences Students Academic Performance: A Case of Rift Valley University, Jimma, Ethiopia. Journal of Education and Practice, 6(22), pp.55-63.

21) Miller, G. and Shih, C.C., 1999. A faculty assessment of the academic rigor of on-and off-campus courses in agriculture. Journal of Agricultural Education, 40, pp.57-65.

22) Tsinidou, M., Gerogiannis, V. and Fitsilis, P., 2010. Evaluation of the factors that determine quality in higher education: an empirical study. Quality Assurance in education, 18(3), pp.227-244.

23) Farooq, M.S., Chaudhry, A.H., Shafiq, M. and Berhanu, G., 2011. Factors affecting students' quality of academic performance: a case of secondary school level. Journal of quality and technology management, 7(2), pp.1-14

24) Fitsilis, P., Gerogiannis, V. and Anthopoulos, L., 2014. Ontologies for software project management: a review. Journal of Software Engineering and Applications, 7(13), p.1096.

25) Adams, J.D. and Jaffe, A.B., 1996. Bounding the effects of R\&D: an investigation using matched establishment-firm data(No. w5544). National bureau of economic research.

\section{AUTHORS PROFILE}

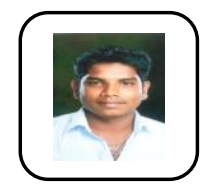

N. Mathankumar Assistant Professor, Department of Science and Humanities, Bharath Institute of Higher Education and Research, Chennai, India.

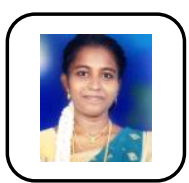

S. Jeni Theresa Assistant Professor, Department of Science and Humanities, Bharath Institute of Higher Education and Research, Chennai, India.

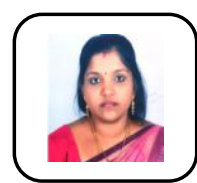

T. Subhalatha Assistant Professor, Department of Science and Humanities, Bharath Institute of Higher Education and Research, Chennai, India. 